\title{
Determinants Of Firm Leadership Structure
}

Richard H. Fosberg, (Email: fosberg@universe.uiwtx.edu), University of the Incarnate Word Sidney Rosenberg, (Email: srosenbe@unf.edu), University of North Florida

\begin{abstract}
In this study, we seek to ascertain some of the factors that determine the leadership structure that a firm chooses to adopt. Our main empirical finding is that both share ownership by officers and directors and by blockholders is inversely related to the probability that a firm will have a unitary leadership structure. These results imply that officers, directors, and blockholders believe that a dual leadership structure is the optimal leadership structure for most firms and that greater share ownership by these groups motivates them to see that the firm adopts that optimal leadership structure. We are also able to confirm Brickley, Coles, and Jarrell's (1997) finding that CEO tenure in office is directly related to the probability that a firm will have a unitary leadership structure. This finding is consistent with the pass-the-baton theory of CEO/Chair succession proposed Vancil (1987).
\end{abstract}

\section{Introduction}

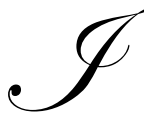

$\mathrm{n}$ recent years, the topic of firm leadership structure has received considerable attention from both practitioners and academics. The main focus of this discussion has been whether a firm should have different people holding the Chairman of the Board and Chief Executive Officer (CEO) positions (a dual leadership structure) or whether it is better for one person to hold both positions (a unitary leadership structure). Agency theorists argue that a dual leadership structure is preferable because a Chair/CEO may inhibit the board in performing one of its most important functions: monitoring, disciplining, and compensating senior managers. This would allow the Chair/CEO to engage in opportunistic behavior that was detrimental to the interests of the firm's shareholders. Others have argued that having a unitary leadership structure does not create significant agency problems for shareholders and that it actually contributes to the effective functioning of the board. They believe that making the CEO the Chairman of the Board promotes better communication and information flow between management and the board and results in better decision making by the board.

Most of the empirical tests of these theories have tried to determine if there is a relationship between leadership structure and firm performance. The results of these studies have been mixed, with some finding support for the agency problem theory and others not. Brickley, Coles, and Jarrell (1997) tested these theories on the firms listed in the 1989 Forbes executive compensation survey and found that firms with different people in the Chair and CEO positions did not exhibit enhanced firm performance. Specifically, firms with a dual leadership structure did not have higher levels of accounting profits than did firms with a unitary leadership structure. Further, they found that adopting a dual leadership structure did not increase the price of a firm's common stock. Baliga, Moyer, and Rao (1996) also found that adopting a dual leadership structure did not increase either accounting profits or the firm's stock price.

Other authors, however, found that separating the Chair and CEO positions led to improved firm performance. Rechner and Dalton (1991) used three accounting measures of profitability to investigate the performance of a sample of Fortune 500 firms that maintained the same leadership structure from 1978 through 1983. These authors found that firms with a dual leadership structure consistently outperformed firms with a unitary leadership structure. Pi and Timme (1993) found some evidence that banks with a dual leadership

Readers with comments or questions are encouraged to contact the authors via email.

structure were more profitable and cost efficient than banks with a unitary leadership structure. Lastly, Fosberg and Nelson (1999) found that firms that changed to a dual leadership structure and maintained that leadership structure for 3 years, exhibited statistically significant improvements in firm performance (profits) over the 3 year period. 
In this paper, we try to determine some of the factors that affect the leadership structure choice that a firm makes. Brickley, Coles, and Jarrell (BCJ) conducted a limited investigation of leadership structure determinants. We will expand on their research by investigating whether factors they did not consider have an impact on firm leadership structure and by using a more sophisticated empirical technique (logistic regression) in our analysis. In our study we find that both share ownership by officers and directors and by blockholders are inversely related to the probability that a firm will employ a unitary leadership structure. This implies that a dual leadership structure better serves the interests of the firm's shareholders. We are also able to confirm BCJ's finding that CEO tenure in office is directly related to the probability that a firm will have a unitary leadership structure. Overall, our results suggest that agency problem considerations better explain a firm's leadership structure choice.

\section{Leadership Structure Theories}

Fama and Jensen (1983) observed that when the benefits of the specialization of management and unrestricted risk-sharing are large, it will be efficient for firms to adopt an ownership structure in which the residual claimants (shareholders) do not play a significant role in managing the firm. Instead, professional managers will be hired to manage the firm on behalf of the shareholders. If employment contracts cannot be costlessly written and enforced, this separation of ownership (residual risk-bearing) and control (decision making authority) may allow managers to engage in opportunistic behavior which will lower the value of the claims of the residual risk-bearers (shareholders). One way to reduce the agency costs associated with this separation of ownership and control is for the firm to adopt a leadership structure in which decision management is separated from decision control. Fama and Jensen define decision management as the right to initiate and implement new proposals for the expenditure of the firm's resources and decision control as the right to ratify and monitor those proposals. By not allowing managers to have both decision management and decision control authority over the same proposals, a series of checks and balances are imposed which make it more difficult for managers to engage in any type of opportunistic behavior.

At the highest levels, this implies that the person with the senior decision management authority (the CEO) should not be allowed to exercise the senior decision control authority as well. Since the board of directors is the highest level decision control structure in the firm, this requires that the board must not be under the control of the CEO. If the board is controlled by the CEO, "this signals the absence of separation of decision management and decision control ..." (Fama and Jensen p. 314). Since the Chairman has the greatest influence over the actions of the board, the separation of decision management and decision control is compromised when the Chairman of the Board is also the CEO of the firm. Thus, requiring the chair and CEO positions to be held by different people will more effectively control the agency problems associated with the separation of ownership and control. This will be called the agency problem theory of leadership structure. Monks and Minow (1995) and Vance (1983) also support the agency problem theory.

Those holding the contrary opinion, including Anderson and Anthony (1986) and Vancil (1987), believe that for the board to function properly it is vital that the board be supplied with timely and accurate information about the operations of the firm. They argue that the requisite information flow to the board can be most effectively accomplished when the CEO is also the Chairman of the Board because the CEO has the most detailed knowledge about the operations of the firm. Thus, allowing the CEO to also be the Chair will put in charge of the board the person best able to supply the board with the timely and accurate information the board needs to perform effectively. Having someone else serve as Chair would result in a reduced flow of information to the board and compromise board decision making. This theory implies that the agency problems created by allowing one person to be both Chair and CEO are relatively small in comparison to the benefits of enhanced information flow to the board. This argument will be termed the information flow theory of leadership structure.

An executive succession theory developed by Vancil (1987), termed the "passing the baton" theory, is closely related to the information flow theory. Under the pass-the-baton theory, when a Chair/CEO nears retirement the CEO title is passed to a potential successor whose performance is then evaluated during a probationary period. If the new CEOs performance is satisfactory, the Chair retires and the successor CEO is given the additional title of Chair. This theory presumes that a unitary leadership structure is the optimal leadership structure and that a dual 
leadership structure is only used as a transitionary device to smooth the transfer to a new Chair/CEO. Consequently, any empirical evidence that supports the pass-the-baton theory can also be interpreted as supporting the information flow theory.

\section{Leadership Structure Determinants}

In this study, three classes of variables will be used to explain the leadership structure choice that a firm makes: performance related variables, CEO longevity variables, and share ownership variables. The performance related variables that will be employed are average ROE (return on equity), change in ROE, and the market to book value of equity ratio. Firm performance and leadership structure will be correlated if firm performance affects the willingness of a firm to adopt a particular leadership structure. For example, poorly performing firms may not be willing to pay an outsider to be board Chair if they can induce the firm's CEO to accept the position with little or no extra compensation. This implies poorly performing (low ROE) firms are more likely to have a unitary leadership structure. Smith and Watts (1992) argue that firms with a large number of good investment opportunities (high growth firms) have more agency problems than low growth firms. If this is the case, the agency problem theory implies that high growth firms should be more likely to employ a dual leadership structure to try to mitigate these agency problems. Following Core, Holthausen, and Larcker (1999) we measure growth opportunities with the market to book value of equity ratio. All else the equal, high growth firms will have more valuable common equity and therefore a higher market to book ratio than similar low growth firms. Consequently, high market to book value firms should be more likely to employ a dual leadership structure. Corroboration of this relationship would be consistent with the agency problem leadership structure theory.

The three longevity variables used are CEO age, the length of CEO employment with the firm, and the length of time the CEO has held the CEO position. The pass-the-baton theory implies that firms with long serving CEOs are more likely to have a unitary leadership structure. This occurs because the longer a CEO has served the more likely they are to have successfully completed their probationary period and assumed the board Chair position. Alternately, the longevity variables could be a proxy for CEO entrenchment. For example, the longer a CEO has served the more time they would have to pack the board with subordinates and friendly outsiders who would be inclined to give the CEO the Chair position as well. Thus, the entrenchment hypothesis also implies that firms with long serving CEOs are more likely to have a unitary leadership structure.

The share ownership variables employed in this study are share ownership by officers and directors, share ownership by blockholders, and number of blockholders. Shareholders of a corporation have a residual claim on the earnings and assets of the firm and therefore bear, proportional to their share ownership, the benefits and costs that result from the actions of the firm's managers and board of directors. As a consequence, a firm's shareholders would prefer that the firm use the leadership structure that maximizes shareholder wealth (the optimal leadership structure). A shareholder's incentive to push management and the board of directors to adopt the optimal leadership structure is directly related to the proportion of the firm's shares that a shareholder owns. This implies that two groups of shareholders who often own large amounts of a firm's stock, officers and directors and blockholders, may have a particular incentive to see that the firm adopts its optimal leadership structure. If officers and directors engage in opportunistic behavior, they bear the costs of this behavior in direct proportion to their share ownership in the firm. Consequently, greater share ownership by officers and directors should make them more likely to choose the leadership structure that maximizes shareholder wealth rather than one that offers more chances to engage in opportunistic behavior. Shareholders who do not have a formal position with the firm have a similar incentive to see that the firm adopts its optimal leadership structure as they bear (proportionately) the costs of not doing so. However, since the typical shareholder owns only a minuscule amount of the firm's shares, this incentive is weak. Therefore, the only shareholders who are likely to have a significant incentive to see that the firm adopts its optimal leadership structure are shareholders who own large amounts of the firm's stock (blockholders). Assuming the above analysis is correct, the agency problem theory implies that share ownership by officers, directors, and blockholders should be greater for dual leadership firms while the information flow theory predicts the opposite. Alternately, BCJ feel that share ownership should be viewed as an agency control mechanism that can substitute for a dual leadership structure in controlling the opportunistic behavior of a firm's CEO. If that is the case, firms with high (low) share ownership by officers and directors or blockholders would be less (more) likely to need a dual leadership structure 
to control the firm's agency problems. We will test to determine what relationship (if any) exists between the variables discussed above and firm leadership structure.

\section{Sample Selection}

The sample of firms used in the study was taken from the Business Week executive compensation studies. Each year Business Week reports the annual compensation and the titles held by the two highest paid executives of approximately 350 of the largest U.S. corporations. For each year from 1990 through 1996, we construct a sample of firms matched by leadership structure and other variables. To be included in the sample for a given year a matched pair of firms had to be found which met the following criteria: ${ }^{1}$

1. A firm with a dual leadership structure and a similar firm with a unitary leadership structure had to be found. A unitary leadership firm was considered similar if it was in the same Business Week industry grouping and of approximately the same size as the dual leadership firm.

2. Each firm must have the same leadership structure and the same CEO for the sample year (year 0) and the previous year (year -1).

3. All necessary data had to be available for both firms. Data used in this study was obtained from Business Week, Forbes, and Disclosure.

This procedure yielded a sample of 160 firms, half with a dual leadership structure and half with a unitary leadership structure. $^{2}$

Table 1 shows the number of sample firms gathered from each sample year. The sample firms are distributed fairly evenly through time and there is no clustering of the sample firms in any year. Summary statistics for selected variables for the sample firms are contained in Table 2. As expected, the sample firms are quite large, with mean annual sales of $\$ 4.874$ billion. On average, the sample firms are also profitable, with mean three year average ROE of $17.0 \%$. The CEOs of the sample firms have an average age of 57.2 years and have been CEO for, on average, 7.81 years (CEO Tenure). The sample firm's officers \& directors own a mean $6.76 \%$ of their firm's common stock while Blockholders (those owning 5\% or more of the firm's shares) own, on average, $16.1 \%$ of their firm's common stock.

\section{Empirical Analysis}

Initially, a paired-sample analysis was used to compare the characteristics of unitary leadership firms with those of dual leadership firms. The results of this analysis are contained in Table 3. Panel A of Table 3 contains data related to the size and performance of the two groups of sample firms. Because the two groups of sample firms were paired by size (Sales), no difference in mean Sales is expected between the two groups of firms. Panel A shows that to be the case. Similarly, no significant difference was found between the two groups of firms average return on equity (Avg. ROE), a result consistent with BCJ's finding that dual leadership firms do not have higher accounting profits than unitary leadership firms. Next, the Market to Book ratio for each group of sample

\section{Table 1}

\section{Distribution of Sample Firms by Year}

This table shows the number of firms that were used in each sample year.

$\begin{array}{ll}1990 & 22 \\ 1991 & 26 \\ 1992 & 22 \\ 1993 & 22 \\ 1994 & 22 \\ 1995 & 24\end{array}$




\begin{tabular}{lr}
1996 & $\underline{22}$ \\
Total & 160 \\
\hline
\end{tabular}

Table 2

\section{Summary Statistics for Selected Variables for the Full Sample of Firms}

This table contains the means and standard deviations of selected variables for all sample firms. Market to Book is the total market value of all common shares divided by the book value of common equity. Avg. ROE is average return on equity over the three most recent years. Firm Tenure and CEO Tenure are the number of years the CEO has been employed at the firm and held the CEO position, respectively. Officers \& Directors is the percentage of the firm's common stock owned by the firm's officers and directors. Number of Blockholders is the number of individuals or institutions that own five percent or more of the firm's common stock. Blockerholders is the total percentage of the firm's common stock owned by all blockholders.

\begin{tabular}{lrc}
\hline & $\underline{\text { Mean }}$ & $\begin{array}{c}\text { Std. } \\
\text { Dev. }\end{array}$ \\
Sales (\$B) & 4.874 & $\underline{ }$ \\
Market to Book & 3.46 & 4.093 \\
Avg. ROE (\%) & 17.0 & 2.61 \\
Age & 57.2 & 8.21 \\
Firm Tenure & 24.1 & 6.62 \\
CEO Tenure & 7.81 & 10.8 \\
Officers \& Directors (\%) & 6.76 & 6.47 \\
Number of Blockholders & 1.68 & 10.7 \\
Blockholders (\%) & 16.1 & 1.44 \\
& & 18.9 \\
\hline
\end{tabular}

$B=$ billion

of sample firms was compared. The Market to Book ratio is calculated by dividing the total market value of a firm's common stock outstanding by the book value of the firm's common stockholders' equity. The mean Market to Book ratio was slightly higher for dual leadership firms but the difference $(-0.17)$ is not statistically significant. The median difference of 0.21 is not significant either (using the Wilcoxon signed-ranks test).

Table 3

\section{Paired-Sample Analysis}

In this table the mean and median values of selected variables were calculated for dual and unitary leadership firms. Statistical tests were used to ascertain if significant differences exist between the means and medians of the two groups of firms. Market to Book is the total market value of all common shares divided by the book value of common equity. Avg. ROE is average return on equity over the three most recent years. Firm Tenure and CEO Tenure are the number of years the $C E O$ has been employed at the firm and held the CEO position, respectively. Officers \& Directors is the percentage of the firm's common stock owned by the firm's officers and directors. Number of Blockholders is the number of individuals or institutions that own five percent or more of the firm's common stock. Blockerholders is the total percentage of the firm's common stock owned by all blockholders. 
Panel A: Size and Performance ${ }^{1}$

\begin{tabular}{ccccc}
\hline & & $\begin{array}{l}\text { Unitary } \\
\text { L. Struct. }\end{array}$ & $\begin{array}{c}\text { Dual } \\
\text { L. Struct. }\end{array}$ & Difference \\
Sales (\$B) & $\begin{array}{c}\text { (Mean) } \\
\text { (t value) }\end{array}$ & 4.866 & 4.882 & -.016 \\
(Median) & & & $(-0.09)$ \\
Avg. ROE (\%) & 17.3 & 16.7 & .189 \\
& & & 0.6 \\
Market to Book & 3.37 & 3.54 & $(0.56)$ \\
& & & 0.4 \\
& & & -0.17 \\
& & & $-0.55)$ \\
\end{tabular}

Panel B: CEO Longevity

\begin{tabular}{lccc}
\hline & $\begin{array}{c}\text { Unitary } \\
\text { L. Struct. }\end{array}$ & $\begin{array}{c}\text { Dual } \\
\text { L. Struct. }\end{array}$ & $\frac{1}{\text { Difference }}$ \\
CEO Tenure & 9.91 & 5.71 & $(4.46)$ \\
& & & $3^{\mathrm{c}}$ \\
Age & 58.5 & 55.9 & $2.6^{\mathrm{c}}$ \\
& & & $(2.66)$ \\
Firm Tenure & 24.8 & 23.4 & $4^{\mathrm{c}}$ \\
& & & 1.39 \\
& & & $0.82)$ \\
& & & 0
\end{tabular}

Table 3 - Paired-Sample Analysis (continued)

\section{Panel C: Share Ownership}

\begin{tabular}{lccc}
\hline & Unitary & Dual & \\
Officers \& Directors (\%) & $\frac{\text { L. Struct. }}{3.98}$ & $\frac{\text { L. Struct. }}{9.53}$ & $\frac{1 \text { Difference }}{-5.55^{\mathrm{c}}}$ \\
& & & $(-3.49)$ \\
& & & $-2.35^{\mathrm{c}}$ \\
Number of Blockholders & 1.53 & 1.83 & -0.30 \\
& 0 & & $(-1.38)$ \\
Blockholders (\%) & 13.1 & 19.1 & $-6.1^{\mathrm{b}}$ \\
& & & $(2.39)$
\end{tabular}




$$
\begin{aligned}
& { }^{1} \text { Rows and columns may not sum due to rounding. } \\
& \qquad \begin{array}{c}
B=\text { billion } \\
a=\text { significant at the } .10 \text { level } \\
b=\text { significant at the } .05 \text { level } \\
c=\text { significant at the } .01 \text { level }
\end{array}
\end{aligned}
$$

Panel B contains a paired-sample analysis of CEO longevity variables. On average, CEOs of unitary leadership firms have been CEOs with their current employer (CEO Tenure) for 9.91 years. This was much longer than the 5.71 year average CEO Tenure of dual leadership firms. The difference of 4.2 years is significant at the .01 level. This result is consistent with the pass-the-baton theory assertion that CEOs go through a probationary period before becoming Chairs. We pursue this issue further by investigating whether other longevity related variables, CEO age and tenure with their current employer, are correlated with firm leadership structure. The mean age for CEOs of unitary leadership firms was 58.5 years while the corresponding figure for the dual leadership firms was 55.9 years. The difference of 2.6 years is significant at the .01 level. Chief executives of unitary leadership firms were employed at their current firms (Firm Tenure) an average of 24.8 years while the corresponding figure for CEOs of dual leadership firms was 23.4 years. The difference in Firm Tenure is not significant. Brickley et al. also find that CEOs of unitary leadership firms are older, have longer tenures as CEO, and have been with their current employer about the same amount of time as CEOs of dual leadership firms. Whether Age or CEO Tenure is a stronger determinant of firm leadership structure will be investigated later using a logistic regression analysis.

Panel C of Table 3 contains an analysis of firm ownership structure. The officers and directors of unitary leadership firms own a mean 3.98\% of the common stock of their companies (Officers \& Directors) compared to the 9.53\% of common stock owned by dual leadership firm officers and directors. The difference of $-5.55 \%$ is significant at the .01 level. The median difference of $-2.35 \%$ is also significant at the .01 level. This result implies that officers and directors believe that a dual leadership structure is the optimal leadership structure for most firms and that greater share ownership by officers and directors motivates them to see that the firm adopts that optimal leadership structure. $^{3}$ We next seek to ascertain whether blockholders' share ownership is correlated with firm leadership structure. On average, unitary leadership firms have 1.53 blockholders per firm (Number of Blockholders) while dual leadership firms have 1.83 blockholders per firm. The difference of -.3 is not statistically significant. However, blockholders (on average) own $13.1 \%$ of the shares of unitary leadership firms while they own (on average) $19.1 \%$ of the shares of dual leadership firms. The difference in blockholder ownership of $6.1 \%$ is significant at the .05 level (figures do not sum due to rounding). The median difference in blockholder ownership of $4.75 \%$ is also significant at the .05 level. This result implies that blockholders believe that a dual leadership structure is the optimal leadership structure for most firms and that greater share ownership by blockholders motivates them to see that the firm adopts that optimal leadership structure.

As a further empirical test, a regression analysis was performed on the data from the sample firms. In this analysis, a binary leadership structure variable was used as the dependent variable. This leadership structure variable takes on a value of one when the firm has a unitary leadership structure and zero otherwise. An empirical methodology designed to handle binary dependent variables, logistic regression, was used in the analysis. In the first regression contained in Table 4, a wide range of performance, tenure, and ownership structure variables are used as independent variables. ${ }^{4}$ As in the paired-sample analysis, no statistically significant relationship was found between Sales, Market to Book, or Avg. ROE and firm leadership structure. The coefficient of Age is positive but not significant while the coefficient of CEO Tenure is both positive and significant at the .01 level. These results contrast with the results from the paired-sample analysis in which a relationship was also found between Age and leadership structure. This suggests that CEO Tenure is the only longevity variable that is truly a determinant of firm leadership structure and that Age has no explanatory power once CEO Tenure is taken into account. This result is consistent with the pass-the-baton theory assertion that CEOs go through a probationary period before being promoted to board 
Chair.

The coefficient of Officers \& Directors is negative and significant at the .01 level. This means that the greater the share ownership by a firm's officers and directors the higher the probability that the firm will have a dual leadership structure. Further, this result supports our previous findings that dual leadership firms tend to have higher share ownership by their officers and directors and is supportive of the agency problem theory of firm leadership structure. As expected, the coefficient of Blockholders is negative, however, it is not statistically significant. To further test for the effect of this variable, a second regression was run in which most of the independent variables that had coefficients that were found not to be statistically significant in the first regression were dropped. The coefficient of Blockholders remains negative but is now significant at the .10 level. This implies that the greater the share ownership by blockholders the greater the probability that the firm will have a dual leadership structure. Again, these results also confirm our paired-sample findings and are supportive of the agency problem theory of leadership structure. Also in the second regression, the coefficients of CEO Tenure and Officers \& Directors retain the signs, magnitudes, and levels of statistical significance found in the first regression.

\section{Conclusion}

In this study, we seek to ascertain some of the factors that determine the leadership structure that a firm chooses to adopt. The main empirical finding in this paper is that both share ownership by officers and directors and by blockholders is inversely related to the probability that a firm will have a unitary leadership structure. These results imply that officers, directors, and blockholders believe that a dual leadership structure is the optimal leadership structure for most firms and that greater share ownership by these groups motivates them to see that the firm adopts that optimal leadership structure. We are also able to confirm BCJ's finding that CEO tenure in office is directly related to the probability that a firm will have a unitary leadership structure. This finding is consistent with the passthe-baton theory of CEO/Chair succession proposed by Vancil where a new CEO must go through a probationary period before they are allowed to assume the Chair position. This result could also imply that the longer a CEO serves the more entrenched they become and the more titles, power, compensation, etc. they accumulate. Further, it was shown that CEO age is not a significant leadership structure determinant but only appears so because of its correlation with CEO tenure in office. Firm performance was not a significant leadership structure determinant.

\section{Table 4}

\section{Logistic Regression Analysis of Leadership Structure}

This table contains the results of a logistic regression analysis in which all sample firms were used. The depended variable is a binary variable that takes on a value of one when the firm has a unitary leadership structure and zero otherwise. Market to Book is the total market value of all common shares divided by the book value of common equity. Avg. ROE is average return on equity over the three most recent years. Firm Tenure and CEO Tenure are the number of years the $C E O$ has been employed at the firm and held the CEO position, respectively. Officers \& Directors is the percentage of the firm's common stock owned by the firm's officers and directors. Number of Blockholders is the number of individuals or institutions that own five percent or more of the firm's common stock. Blockerholders is the total percentage of the firm's common stock owned by all blockholders.

$\begin{array}{lcc}\text { Intercept } & -1.73 & -.365 \\ \text { (Chi-Square) } & (0.85) & (0.80) \\ \text { Sales (\$B) } & .001 & .001 \\ & (0.02) & (0.13) \\ \text { Market to Book } & -.092 & - \\ & (0.99) & - \\ \text { Avg. ROE (\%) } & .023 & \\ & (0.57) & -\end{array}$




$\begin{array}{llr} & (0.59) & \\ \text { CEO Tenure } & .130^{\mathrm{c}} & .139^{\mathrm{c}} \\ & (11.4) & (14.4) \\ \text { Officers \& Directors (\%) } & -.081^{\mathrm{c}} & -.083^{\mathrm{c}} \\ & (7.05) & (7.36) \\ \text { Blockholders (\%) } & -.015 & -.017^{\mathrm{a}} \\ \text { Chi - Square } & (2.23) & (2.96) \\ & 37.9^{\mathrm{c}} & 36.3^{\mathrm{c}} \\ & B=\text { billion } \\ & a=\text { significant at the .10 level } \\ b & =\text { significant at the .05 level } \\ c & =\text { significant at the .01 level }\end{array}$

\section{Suggestions for Future Research}

Other factors such as firm risk, capital structure, and composition of the board of directors may also impact the leadership structure that a firm selects. The effect of these factors on leadership structure choice certainly merits investigation. Also, it would be interesting to know if the relationships found in this study hold for banks or if government regulation affects the choice of firm leadership structure.

\section{Endnotes}

1. Firms in the banking industry were not included in this study.

2. Firms may appear in more than one sample year. If a large number of firms appear in multiple years this may cause a positive correlation in some of the data used in this study. That would tend to cause the standard errors used in statistical tests to be too low and, consequently, the statistical significance of the empirical tests to be overstated. To mitigate this problem, the sample firms were selected so as to induce as much change in the yearly sample of firms as possible. Our selection procedure was largely successful as only two firms that appear in the 1990 sample of firms also appear in the 1996 sample. Therefore, statistical bias should have little or no effect on our results.

3. Brickley et al. find that CEOs of unitary leadership firms own a greater proportion of their firm's common stock than dual leadership firm CEOs.

4. As the sample firms were paired by Sales, we do not expect this variable to be correlated with firm leadership structure. Nevertheless, we included Sales in the regression analysis in case the size matching did not account for all size effects.

\section{References}

1. Anderson, C. and R. Anthony. The New Corporate Directors, John Wiley \& Sons, New York, 1986.

2. Baliga, B., Moyer, R., and R. Rao. "CEO Duality and Firm Performance: What's the Fuss." Strategic Management Journal, 17 (1996), 41-53.

3. Brickley, J., J. Coles, and G. Jarrell. "Leadership structure: Separating the CEO and Chairman of the Board," Journal of Corporate Finance, 3 (1997), 189-220.

4. Core, J., R. Holthausen, and D. Larcker. "Corporate Governance, Chief Executive Officer Compensation, and Firm Performance," Journal of Financial Economics, 51 (1999), 371-4-6.

5. Fama, E. and M. Jensen. "Separation of Ownership and Control," Journal of Law and Economics, 26 (1983), 301-325.

6. $\quad$ Fosberg, R. and M. Nelson. "Leadership Structure and Firm Performance," International Review of Financial Analysis, (1999), 83-96.

7. Jensen, M. and K. Murphy. "Performance Pay and Top-Management Incentives," Journal of Political Economy, 98 (1990), 225-264.

8. Monks, R. and N. Minow. Corporate Governance. Blackwell, Cambridge, 1995. 
9. Murphy, K. "Corporate Performance and Managerial Remuneration," Journal of Accounting and Economics, 7 (1985), 11-42.

10. Pi, L. and S. Timme. "Corporate Control and Bank Efficiency," Journal of Banking and Finance, 17 (1993), 515-530.

11. Rechner, P. and D. Dalton. "CEO Duality and Organizational Performance: A Longitudinal Analysis," Strategic Management Journal, 12 (1991), 155-160.

12. Smith, C. and R. Watts. "The Investment Opportunity Set and Corporate Financing, Dividend, and Compensation Policies," Journal of Financial Economics, 32 (1992), 263-92.

13. Vance, S. Corporate Leadership: Boards, Directors and Strategy, McGraw-Hill, New York, 1983.

14. Vancil, R. Passing the Baton: Managing the Process of CEO Succession, Harvard Business School Press, Boston, 1987. 